\title{
Pengasuhan Berbasis Kekuatan Karakter Dan Keterlibatan Diri Pada Mahasiswa
}

\author{
Marissa Chitra Sulastra1; Vida Handayani ${ }^{2}$ \\ Fakultas Psikologi, Universitas Kristen Maranatha, Jl. Prof. drg. Surya Sumantri No. 65, Bandung, \\ Indonesia 40164 \\ e-mail: marissachitra@gmail.com
}

Article History:
Received
$28-09-2020$
Review
$27-10-2020$
Revised
$26-11-2020$
Accepted
$28-11-2020$
Published
$10-12-2020$

\begin{abstract}
The purpose of this research is to get a correlation between strength-based parenting (SBP) and engagement among college students. The background of this research is the importance of engagement in college. Engagement is known as human adaptive functioning in their life. Engagement is important because it can help college students to direct their efforts and complete assignments seriously. It is necessary to have proper parenting practiced by parents through the application of positive psychology parenting, based on the strengths of college students (SBP) so that students accustomed to using their strengths and they can do their duties in daily life optimally. Hopefully, they'll become more engaged in carrying out their duties as a college student. The benefits of this research can help college students, parents and educators work together in helping college students get engaged with their studies. This research was conducted on 158 students of the Faculty of Psychology University ' $X$.' The method used in this research is the correlation method. The survey technique was carried out to collect data. Based on this research, the correlation test's result is $r$ $=0.455, p=0,000=<0.001$ which means there is a significant positive correlation between SBP and engagement.
\end{abstract}

Key Words: Strength-based Parenting (SBP), Engagement, Correlation

Abstrak. Penelitian ini bertujuan untuk mendapatkan gambaran hubungan pengasuhan berbasis kekuatan karakter dan keterlibatan yang dimiliki oleh mahasiswa. Penelitian ini dilatarbelakangi oleh pentingnya keterlibatan diri di bidang perkuliahan pada mahasiswa sebagai bentuk fungsi adaptif diri dalam kehidupannya. Keterlibatan diri menjadi penting karena dapat mengarahkan mahasiswa untuk mengarahkan usahanya untuk belajar dan menyelesaikan tugas dengan sungguh. Diperlukan adanya pengasuhan yang tepat oleh orangtua melalui penerapan pengasuhan positif berdasarkan kekuatan karakter yang dimiliki mahasiswa agar mahasiswa terbiasa untuk menggunakan kekuatan karakter yang dimiliki sehingga dapat lebih optimal dalam melakukan tugasnya dalam kehidupan sehari-hari. Sehingga diharapkan mereka akan menjadi lebih melibatkan dirinya dalam melakukan tugasnya sebagai seorang mahasiswa. Manfaat penelitian ini dapat membantu mahasiswa, orangtua dan pendidik untuk saling bekerja sama dalam membantu mahasiswa agar melibatkan diri dengan studinya. Penelitian ini dilakukan pada 158 mahasiswa Fakultas Psikologi Universitas ' $\mathrm{X}$ ' Metode yang digunakan adalah metode korelasional. Teknik survey dilakukan untuk pengambilan data variabel yang akan diukur. Berdasarkan penelitian, diperoleh hasil uji korelasi $r=0,455, p=0,000=<0,001$ sehinga dapat dikatakan bahwa terdapat korelasi positif yang signifikan antara pengasuhan berbasis kekuatan karakter dan keterlibatan diri.

Kata Kunci: Pengasuhan Berbasis Kekuatan Karakter, Keterlibatan Diri, Korelasi 
Philanthropy Journal of Psychology

Volume 4 Nomor 2 (2020), 143-157

ISSN 2580-6076 (Print), ISSN 2580-8532 (Online)

\section{Pendahuluan}

Pendidikan merupakan hal yang penting bagi kemajuan individu. Indonesia mewajibkan pendidikan hingga jenjang SMA, namun seiring perkembangan zaman, ijazah SMA saja dirasakan tidak cukup bagi individu untuk dapat bersaing dalam dunia kerja dan mendapatkan pekerjaan yang dianggap memuaskan. Jenjang kuliah strata 1 (S-1) menjadi pilihan bagi kebanyakan orangtua untuk menyekolahkan anaknya agar lebih siap bersaing. Pendidikan S-1 menuntut anak didiknya dapat melakukan pengembangan keilmuan berdasarkan program studinya masing-masing.

Sebagai mahasiswa S1, terdapat tuntutan agar mahasiswa bersedia untuk terlibat aktif dalam proses perkuliahan. Bukan hanya duduk diam untuk mendengarkan materi dosen, tapi diharapkan mahasiswa juga dapat memberikan sumbangsih terhadap proses belajar-mengajar tersebut. Sumbangsih yang dimaksud di antaranya adalah mahasiswa diharapkan dapat mempelajari materi secara mandiri, berdiskusi bersama untuk membantu pemahaman materinya, terlibat dalam tanyajawab dan pemberian masukan. Artinya, perlu ada suatu keterlibatan pada mahasiswa untuk melakukan kegiatan perkuliahan sehingga ia bisa berhasil.

Indeks Prestasi Kumulatif (IPK) menjadi salah satu hasil penilaian yang menandakan mahasiswa berhasil dalam kegiatan belajar yang ia tempuh. Dapat dikatakan, bahwa IPK bisa menjadi sistem pengukur untuk mengetahui prestasi akademik yang dimiliki mahasiswa. Mahasiswa dengan IPK tinggi (di atas 3.50) dinilai lebih menguasai materi, lebih berprestasi dibandingkan mahasiswa lainnya dan dianggap dapat menunjukkan performa kerja yang lebih baik.

Akan tetapi, prestasi akademik merupakan produk akhir dari usaha mahasiswa dalam belajar. Dalam prosesnya, mahasiswa memerlukan sikap untuk benar-benar terlibat penuh dengan tugas dan kegiatan dalam perkuliahan. Lebih dari itu, mahasiswa juga diharapkan dapat terlibat penuh dengan orang-orang, aktivitas, tujuan, nilai-nilai, dan tempat di mana ia berkuliah. Keterlibatan inilah yang disebut sebagai keterlibatan diri (E. A. Skinner, Kindermann, \& Furrer, 2009)

Keterlibatan diri menjadi hal yang penting untuk keberhasilan mahasiswa dalam kehidupan akademiknya. Ketika mahasiswa memiliki keterlibatan diri yang baik terhadap perkuliahannya, ia akan menunjukkan usaha mental untuk tetap menjaga atensi dan konsenterasi terhadap kegiatan perkuliahan, serta berusaha untuk tetap tekun dan mengerahkan tenaga untuk mengikuti kegiatan perkuliahan (keterlibatan perilaku). Sehingga mahasiswa yang melibatkan dirinya, tidak akan menunjukkan sikap pasif, minim inisiatif, tidak fokus dan mudah menyerah saat mengikuti kegiatan perkuliahan (ketidakpuasan perilaku). Selain itu, mahasiswa juga merasakan perasaan positif 
Philanthropy Journal of Psychology

Volume 4 Nomor 2 (2020), 143-157

ISSN 2580-6076 (Print), ISSN 2580-8532 (Online)

terhadap kegiatan perkuliahan seperti antusias, tertarik dan menikmati (keterlibatan emosi). Sehingga mahasiswa tidak akan merasakan emosi yang melemahkan diri seperti lelah-sedih-bosan, emosi yang mengasingkan diri seperti frustrasi-marah, dan emosi yang menekan diri seperti kecemasan saat mengikuti kegiatan perkuliahan (ketidakpuasan emosi) (Skinner, E. A., Kindermann, T. A., \& Furrer, C. J., 2009; Skinner, E., Furrer, C., Marchand, G., \& Kindermann, T., 2008).

Demikian juga sebaliknya, saat mahasiswa menghayati keterlibatan diri untuk berkuliah kurang memadai, maka mereka akan menunjukkan sikap yang pasif dalam berkuliah, seperti enggan untuk mengerjakan tugas atau bahkan untuk sekedar berdiskusi di dalam proses perkuliahan. Atensi terhadap kegiatan perkuliahan pun menjadi mudah terganggu, karena mahasiswa tidak menganggap penting perkuliahan tersebut. Secara emosi, mahasiswa yang tidak melibatkan diri dalam perkuliahan lebih mudah merasakan emosi negatif seperti sedih, marah, cemas saat mengikuti kegiatan perkuliahan. Mereka pun sulit untuk menikmati jalannya kegiatan perkuliahan (Skinner, E. A., Kindermann, T. A., \& Furrer, C. J., 2009; Skinner, E., Furrer, C., Marchand, G., \& Kindermann, T., 2008).

Mahasiswa sudah masuk usia dewasa awal, secara tugas perkembangan seharusnya mereka sudah dapat hidup mandiri tanpa orangtua. Namun mahasiswa yang tinggal di budaya timur, termasuk Indonesia, sebagian besar masih hidup dengan orangtuanya. Kalaupun mereka tinggal sendiri (mengontrak atau menyewa kost-an) namun pembiayaan masih dilakukan oleh orangtuanya. Orangtua masih bertanggung jawab terhadap kehidupan para mahasiswa sebagai anak mereka. Artinya, peran serta orangtua masih terus dilakukan meskipun anak-anaknya sudah beranjak dewasa dan menempuh pendidikan sebagai mahasiswa.

Menurut teori sistem ekologi dari Bronfenbenner (1977, dalam Papalia 2014), lingkungan terdekat pada individu disebut sebagai sistem-mikro, yang salah satunya adalah orangtua. Terjadi proses interaksi antara orangtua dan anak. Orangtua akan memberikan pengaruh tertentu kepada anaknya dengan cara mencontohkan, mengajarkan, berdiskusi, memberikan aturan, mengungkapkan kasih sayang, dan mengasuh anaknya dengan cara tertentu. Ketika orangtua memberikan pengaruh positif, seperti mendukung anak untuk tumbuh dan berkembang sesuai kapasitas diri, maka anak akan dapat berkembang secara lebih optimal dan mampu memanfaatkan berbagai potensi di dalam diri untuk menjalankan kehidupannya.

Dapat dikatakan, bahwa peran serta orangtua masih dibutuhkan oleh mahasiswa untuk mengembangkan diri, termasuk mengembangkan keterlibatan diri-nya. Mahasiswa merupakan 
Philanthropy Journal of Psychology

Volume 4 Nomor 2 (2020), 143-157

ISSN 2580-6076 (Print), ISSN 2580-8532 (Online)

anak dari orangtuanya. Pengasuhan adalah dasar bagi orangtua dalam memainkan peranannya kepada mahasiswa. Baumrind menciptakan teori pengasuhan yang melibatkan dua dimensi utama yaitu kontrol dan aturan dari orangtua serta kehangatan dan kasih sayang dari orangtua. Ketika kedua dimensi tersebut memiliki derajat yang sama tingginya, maka pengasuhan demokratis lah yang akan muncul.

Pengasuhan demokratis dinyatakan memiliki pengaruh yang baik terhadap perkembangan anak, termasuk salah satunya adalah perkembangan anak dalam belajar dan bersekolah. Dikatakan pula bahwa pengasuhan demokratis dapat memperkuat keterlibatan diri pada anak terhadap sekolah. (Steinberg, Lamborn, Dornbusch, \& Darling, 1992). Pada saat ini, berkembang pula sebuah teori mengenai pengasuhan psikologi positif yang membahas mengenai peran pengasuhan orangtua dalam menciptakan situasi keluarga yang mengembangkan emosi positif bagi anak dan menemukan serta memanfaatkan kekuatan karakter pada anak, sebagai usaha untuk membentuk kesejahteraan anak (Seligman, 2002, Kyriazos \& Stalikas, 2018).

Pengasuhan berbasis kekuatan karakter adalah pengembangan dari pengasuhan demokratis menurut Baumrind di mana orangtua membantu mengembangkan konstelasi unik dari talenta (berbasis performa) dan karakter (berbasis kepribadian) pada anak. Anak yang baik secara karakter adalah anak yang dapat memanfaatkan kekuatan yang dimiliki sambil tetap memperbaiki kekurangannya karena ia memiliki identitas diri yang kokoh. Identitas diri yang kokoh memberikan dasar yang kuat bagi anak untuk menyadari dan menunjukkan area yang butuh untuk dikembangkan Artinya, orangtua yang mempraktekkan pengasuhan berbasis kekuatan karakter akan mengasuh anak dengan tujuan untuk dapat mengembangkan performa dan kepribadian anak yang dianggap menjadi kekuatannya. (Waters, 2017).

Menurut Waters, kekuatan karakter anak adalah keterampilan, kemampuan, minat, karakter, sifat atau bakat yang dimiliki oleh seseorang. Kekuatan karakter dimiliki secara natural/ bawaan sejak lahir dan akan mengarahkan individu untuk melakukan perilaku tertentu yang berpola, penggunaan kekuatan dapat menimbulkan dampak yang positif pada individu maupun lingkungannya. Terdapat tiga elemen penting di dalam kekuatan karakter yaitu performa (seberapa baik seseorang dalam menampilkan kekuatan tertentu), energi (seberapa baik perasaannya saat menggunakan kekuatan tersebut) dan tingkat penggunaan (seberapa sering seseorang memilih untuk menggunakan kekuatan karakter tersebut) (Waters, 2017)

Pengasuhan berbasis kekuatan karakter adalah gaya pengasuhan yang bertujuan untuk "mengidentifikasi dan mengolah kondisi positif, proses positif dan kualitas positif" pada anak. 
Philanthropy Journal of Psychology

Volume 4 Nomor 2 (2020), 143-157

ISSN 2580-6076 (Print), ISSN 2580-8532 (Online)

Artinya, orangtua yang berorientasi pada pengasuhan berbasis kekuatan karakter akan melakukan (a) mengetahui dan mengakui hal yang dapat dilakukan anak secara optimal sebagai kekuatan karakter-nya / pengetahuan kekuatan karakter (b) mendukung anak untuk menggunakan dan mengembangkan kekuatan karakternya, baik yang sudah disadari maupun yang belum disadari / penggunaan kekuatan karakter (Jach, Hayley K., Jessie Sun., Daniel Loton., Tan-Chyuan Chin; Lea E. Waters, 2018).

Pengasuhan berbasis kekuatan karakter dilakukan oleh orangtua terhadap mahasiswa, sebagai anaknya. Orangtua akan berusaha untuk membantu mahasiswa mengembangkan kekuatan karakter yang ada dalam diri, baik dalam bentuk keterampilan, kemampuan, minat, karakter, sifat atau bakat. Ketika orangtua menunjukkan praktek pengasuhan berbasis kekuatan karakter yang tinggi pada mahasiswa, orangtua akan mengetahui kekuatan karakter yang dimiliki oleh mahasiswa tersebut dan mendukung mahasiswa untuk menggunakan kekuatan karakternya secara terus menerus.

Ketika orangtua menerapkan pengasuhan berbasis kekuatan karakter kepada mahasiswa, mahasiswa akan lebih terdorong untuk menggunakan kelebihan yang dimilikinya. Kelebihan itu dapat dimanfaatkan dalam kehidupan sehari-hari. Salah satunya adalah dalam kegiatan belajar. Kegiatan belajar bukan hanya memanfaatkan aspek kecerdasan saja. IQ (intelligence quotient) dinyatakan bukan sebagai penentu utama dari keberhasilan pendidikan anak. Aspek emosi dan perilaku dapat menjadi aspek penunjang untuk mencapai keberhasilan dalam belajar. Pemanfaatan aspek kecerdasan, aspek emosi, dan aspek perilaku dalam belajar merupakan bentuk dari kekuatan karakter pada mahasiswa. Saat kekuatan karakter anak dapat dimanfaatkan dengan optimal, tentunya keterlibatan diri untuk mengikuti kegiatan perkuliahan diharapkan akan lebih mudah diraih.

Hal ini diperkuat pula dengan hasil penelitian yang dilakukan oleh Waters, dkk yang menunjukkan bahwa pengasuhan berbasis kekuatan karakter pada anak memiliki hubungan yang signifikan dengan keterlibatan diri dalam bersekolah (L. E. Waters, Loton, \& Jach, 2019). Walaupun sudah terdapat penelitian yang menunjukkan adanya hubungan antara pengasuhan berbasis kekuatan karakter dan keterlibatan diri, namun penelitian pengasuhan berbasis kekuatan karakter nampaknya belum ada di Indonesia. Peneliti ingin meneliti secara lebih mendalam bagaimana hubungan antara pengasuhan berbasis karakter dan keterlibatan diri di bidang perkuliahan pada mahasiswa. 
Philanthropy Journal of Psychology

Volume 4 Nomor 2 (2020), 143-157

ISSN 2580-6076 (Print), ISSN 2580-8532 (Online)

Hipotesis yang akan diuji dalam penelitian ini adalah: "Terdapat hubungan antara pengasuhan berbasis kekuatan karakter dan keterlibatan diri pada mahasiswa"

\section{Metode}

Disain penelitian yang dilakukan adalam penelitian ini adalah disain penelitian kuantitatif. Jenis metode penelitian kuantitatif yang digunakan dalam penelitian ini adalah metode korelasional. Untuk mengetahui hubungan antara variabel pengasuhan berbasis kekuatan karakter dan variabel keterlibatan diri. Uji korelasional dilakukan dengan perhitungan Spearman's Rho karena penyebaran data tidak normal.

Populasi sasaran adalah mahasiswa aktif Fakultas Psikologi Universitas "X" di Kota Bandung. Sampel penelitian sebanyak 158 responden yang dijaring dengan teknik sampling purposive sampling. Teknik survei dilakukan untuk pengambilan data variabel yang akan diukur. Proses penyebaran kuesioner dilakukan melalui google form. Tautan google form akan dibagikan kepada seluruh mahasiswa yang menjadi subjek penelitian.

Alat ukur yang digunakan dalam penelitian ini terdiri dari dua kuesioner yaitu kuesioner pengasuhan berbasis kekuatan karaker dan keterlibatan diri. Kuesioner pengasuhan berbasis kekuatan karakter terdiri dari 14 aitem berdasarkan teori pengasuhan berbasis kekuatan karakter dari Lea Waters (2017). Kuesioner pengasuhan berbasis kekuatan karakter terdiri dari 2 komponen yaitu yaitu pengetahuan kekuatan karakter dan penggunaan kekuatan karakter. Komponen pengetahuan kekuatan karakter terdiri dari 7 aitem dan komponen penggunan kekuatan karakter terdiri dari 7 aitem. Ketika orangtua memiliki pengetahuan yang tinggi mengenai kekuatan karakter mahasiswa disertai dengan penggunaan yang tinggi mengenai kekuatan karakter mahasiswa, maka semakin tinggi pula pengasuhan berbasis kekuatan karakter. Skala untuk kuesioner pengasuhan berbasis kekuatan karakter menggunakan skala Likert, terdiri dari 1 - 5 (Sangat Tidak Setuju - Sangat Setuju).

Kuesioner keterlibatan diri terdiri dari 27 aitem yang disusun berdasarkan 4 komponen menurut Skinner, Kindremann, \& Furrer (2009) yaitu keterlibatan perilaku, keterlibatan emosi, ketidakpuasan perilaku dan ketidakpuasan emosi. Komponen keterlibatan perilaku, keterlibatan emosi dan ketidakpuasan perilaku masing-masing terdiri dari 5 aitem. Sementara komponen ketidakpuasan emosi terdiri dari 12 aitem. Ketika mahasiswa memiliki keterlibatan perilaku dan keterlibatan emosi yang tinggi dalam perkuliahan, namun memiliki ketidakpuasan perilaku dan ketidakpuasan emosi yang rendah dalam perkuliahan, maka semakin tinggi keterlibatan diri 
Philanthropy Journal of Psychology

Volume 4 Nomor 2 (2020), 143-157

ISSN 2580-6076 (Print), ISSN 2580-8532 (Online)

mahasiswa dalam bidang perkuliahan. Skala untuk kuesioner keterlibatan diri menggunakan skala Likert, terdiri dari 1 - 4 (Sangat Tidak Sesuai - Sangat Sesuai).

Analisa data uji reliabilitas dan validitas dilakukan dengan bantuan aplikasi software. Berdasarkan uji reliabilitas alpha cronbach's yang dilakukan pada kuesioner pengasuhan berbasis kekuatan karakter dan keterlibatan diri, diperoleh nilai reliabilitas sebesar 0,926 untuk kuesioner pengasuhan berbasis kekuatan karakter dan nilai reliabilitas sebesar 0,884 untuk kuesioner keterlibatan diri. Sementara uji validitas dilakukan dengan menghitung internal consistency pada kuesioner pengasuhan berbasis kekuatan karakter dan keterlibatan diri. Diperoleh hasil nilai validitas kuesioner pengasuhan berbasis kekuatan karakter beriksar 0,438 - 0,759 dan kuesioner keterlibatan diri berkisar 0,301 - 0,628. Maka dapat dikatakan bahwa alat ukur pengasuhan berbasis kekuatan karakter dan keterlibatan diri merupakan alat ukur yang valid dan reliabel.

\section{Hasil}

Berdasarkan penelitian yang sudah dilakukan maka dapat diperoleh hasil seperti di bawah ini:

Tabel 1. Hasil Deskripsi Data Pengasuhan Berbasis Kekuatan Karakter dan Keterlibatan Diri

\begin{tabular}{lccccc}
\hline \multicolumn{1}{c}{ Variabel } & $\mathrm{N}$ & Mean & SD & Mean & SD \\
\hline $\begin{array}{l}\text { Pengasuhan Berbasis } \\
\text { Kekuatan Karakter }\end{array}$ & 158 & 51,77 & 8,69 & 42 & 9,33 \\
Keterlibatan Diri & 158 & 77,46 & 9,96 & 67,5 & 13,5 \\
Valid N (Listwise) & 158 & & & & \\
\hline
\end{tabular}

Dapat dilihat dari tabel 1. bahwa mean empirik untuk kuesioner keterlibatan diri adalah 51,77 dan mean hipotetiknya adalah 42. Ketika mean empirik > mean hipotetik, maka jawaban seluruh responden mengarah pada tinggi. Artinya, mahasiswa menghayati bahwa orangtua sudah melakukan pengasuhan berbasis kekuatan karakter dalam tingkatan yang tinggi.

Sementara, mean empirik untuk kuesioner keterlibatan diri adalah 77,46 dan mean hipotetiknya adalah 67,5. Ketika mean empirik > mean hipotetik, maka jawaban seluruh responden mengarah pada tinggi. Artinya, mahasiswa sudah melibatkan diri terhadap perkuliahan dengan tingkatan yang tinggi.

Tabel 2. Kategorisasi Pengasuhan Berbasis Kekuatan Karakter

\begin{tabular}{lllll}
\hline Variabel & Rentang Nilai & Kategori & Jumlah (n) & Presentase \\
\hline Pengasuhan & $\mathrm{x} \leq 20$ & Rendah (low) & 0 & $0 \%$ \\
Berbasis Kekuatan & $20<\mathrm{x} \leq 40$ & Sedang (medium) & 17 & $11 \%$
\end{tabular}


Philanthropy Journal of Psychology

Volume 4 Nomor 2 (2020), 143-157

ISSN 2580-6076 (Print), ISSN 2580-8532 (Online)

Karakter

\begin{tabular}{l}
$40<\mathrm{x} \leq 60$ \\
$70 \leq \mathrm{x}$ \\
\hline Jumlah
\end{tabular}

Tinggi (high use)

116

$73 \%$

Sangat Tinggi (super)

25

$16 \%$

158

$100 \%$

Kategori skor pengasuhan berbasis kekuatan karakter didasarkan pada norma yang sudah ditentukan oleh Lea Waters (2017). Berdasarkan tabel 2. diperoleh hasil bahwa 116 (73\%) dari 158 mahasiswa memiliki pengasuhan berbasis kekuatan karakter yang tergolong tinggi (high use). Sementara $0(0 \%)$ dari 158 mahasiswa memiliki pengasuhan berbasis kekuatan karakter yang tergolong rendah (low).

Berdasarkan tabel 1. dan tabel 2. menandakan bahwa orangtua yang dimiliki oleh responden sudah mengetahui dan mengakui kekuatan karakter yang dimiliki mahasiswa. Orangtua juga sudah mendukung mahasiswa untuk menggunakan dan mengembangkan kekuatan karakternya.

Tabel 3. Kategorisasi Keterlibatan Diri

\begin{tabular}{lllll}
\hline Variabel & Rentang Nilai & Kategori & Jumlah (n) & Presentase \\
\hline Keterlibatan Diri & $\mathrm{x} \leq 47,25$ & Sangat Rendah & 0 & $0 \%$ \\
& $47,25<\mathrm{x} \leq 60,75$ & Rendah & 7 & $4,4 \%$ \\
& $60,75<\mathrm{x} \leq 74,25$ & Sedang & 59 & $37,3 \%$ \\
& $74,25<\mathrm{x} \leq 87,75$ & Tinggi & 63 & $39,9 \%$ \\
& $87,75 \leq \mathrm{x}$ & Sangat Tinggi & 29 & $18,4 \%$ \\
\cline { 2 - 5 } & Jumlah & & 158 & $100 \%$ \\
\hline
\end{tabular}

Kategori skor pengasuhan berbasis kekuatan karakter didasarkan pada perhitungan kategorisasi dari Azwar (2012) yang dibagi ke dalam 5 kategori. Berdasarkan tabel 2. diperoleh hasil bahwa $63(39,9 \%)$ dari 158 mahasiswa memiliki keterlibatan diri yang tergolong tinggi. Sementara 7 (4,4\%) dari 158 mahasiswa memiliki keterlibatan diri yang tergolong rendah.

Berdasarkan tabel 1. dan tabel 3. menandakan bahwa mahasiswa menunjukan keterlibatan yang penuh terhadap perkuliahannya. Mereka lebih banyak menunjukkan perilaku optimal saat melakukan proses belajar-mengajar di kelas dan mampu memfokuskan perhatian saat belajar. Secara emosi, mahasiswa juga lebih banyak menghayati adanya emosi positif saat berkuliah daripada emosi negatif.

Tabel 4. Hasil Uji Korelasi Pengasuhan Berbasis Kekuatan Karakter dan Keterlibatan Diri

\begin{tabular}{lccccc}
\hline \multicolumn{1}{c}{ Variabel } & $\mathrm{N}$ & $\mathrm{M}$ & $\mathrm{SD}$ & 1 & 2 \\
\hline 1. Pengasuhan Berbasis Kekuatan Karakter & 158 & 51,77 & 8,69 & & \\
2. Keterlibatan Diri & 158 & 77,46 & 9,96 & $0,455^{* *}$ & \\
\hline
\end{tabular}

**. Korelasi signifikan pada level 0,01 (2-tailed). 
Philanthropy Journal of Psychology

Volume 4 Nomor 2 (2020), 143-157

ISSN 2580-6076 (Print), ISSN 2580-8532 (Online)

Untuk memahami korelasi pengasuhan berbasis kekuatan karakter dan keterlibatan secara lebih objektif. Uji korelasi dilakukan dengan perhitungan Spearman's rho karena distribusi data pengasuhan berbasis kekuatan karakter dinyatakan normal $(Z=0,088, p<0,05)$ namun distribusi data keterlibatan diri dinyatakan tidak normal $(Z=0,059, p>0,05)$. Adapun hasil uji linearitas menyatakan bahwa terdapat hubungan yang bersifat linear antara data pengasuhan berbasis kekuatan karakter dan keterlibatan diri pada mahasiswa $(F=29,83, p<0,05)$.

Berdasarkan hasil uji korelasi, diperoleh nilai koefisien korelasi sebesar $r=0,455(p=0,000=$ $<0,01$ ) artinya, terdapat hubungan yang positif dan signifikan antara pengasuhan berbasis kekuatan karakter dan keterlibatan diri. Semakin tinggi pengasuhan berbasis kekuatan karakter, maka akan semakin tinggi pula keterlibatan diri.

\section{Diskusi}

Hasil uji analisis data yang telah dilakukan, diperoleh nilai koefisien korelasi sebesar $\mathrm{r}=$ $0,455(\mathrm{p}=0,000=<0,01)$ yang menunjukkan bahwa hipotesis dalam penelitian ini diterima. Nilai koefesien korelasi (r) yang bersifat positif menunjukkan bahwa semakin tinggi skor pengasuhan berbasis kekuatan karakter maka semakin tinggi pula keterlibatan diri. Artinya, terdapat hubungan antara pengasuhan berbasis kekuatan karakter dengan keterlibatan diri pada mahasiswa. Jika pengasuhan berbasis kekuatan karakter dilakukan oleh orangtua terhadap mahasiswa melalui adanya kesadaran orangtua terhadap kekuatan karakter mahasiswa (pengetahuan kekuatan karakter) dan kesediaan orangtua untuk mendorong mahasiswa menggunakan kekuatan karakternya (penggunaan kekuatan karakter), maka dapat meningkatkan keterlibatan diri mahasiswa terhadap perkuliahannya. Mahasiswa dapat menunjukkan sikap untuk lebih bersedia terlibat dalam kegiatan perkuliahan secara fokus dan penuh (keterlibatan perilaku), menghayati perasaan positif saat sedang terlibat dalam perkuliahan (keterlibatan emosi), tidak bersikap malas dan mudah menyerah dalam perkuliahan (ketidakpuasan perilaku) dan tidak menghayati perasaan negatif yang dapat mengganggu kegiatan perkuliahan (ketidakpuasan emosi).

Hubungan pengasuhan berbasis kekuatan karakter dengan keterlibatan diri mahasiswa di bidang perkuliahan memiliki nilai koefisien korelasi 0,455. Artinya, terdapat hubungan yang cukup antara pengasuhan berbasis kekuatan karakter dengan keterlibatan diri mahasiswa di bidang perkuliahan. Adapun nilai koefisien determinasi $\mathrm{r}^{2}$ adalah 0,21 . Hal ini menunjukkan bahwa peningkatan dan penurunan keterlibatan diri mahasiswa di bidang perkuliahan dipengaruhi oleh pengasuhan berbasis karakter sebesar 21\%, sedangkan 79\% lainnya dipengaruhi oleh faktor lain 
Philanthropy Journal of Psychology

Volume 4 Nomor 2 (2020), 143-157

ISSN 2580-6076 (Print), ISSN 2580-8532 (Online)

misalnya seperti kondisi internal (usia perkembangan, tingkat kematangan kognitif, dll) dan kondisi eksternal (dukungan teman, budaya, iklim belajar di kampus, dll) (Christenson, S. L., Wylie, C., \& Reschly, A. L., 2012). Adapun pengasuhan orangtua merupakan salah satu kondisi eksternal yang dapat memberikan pengaruh terhadap peningkatan dan penurunan keterlibatan diri mahasiswa.

Indonesia sebagai bagian dari budaya timur memiliki nilai kolektivistik yang dianut oleh masyarakatnya. Kebersamaan keluarga menjadi salah satu bentuk dari nilai kolektivistik ini. Ciri lain dari kebudaya kolektivistik adalah individu yang dilahirkan dalam suatu keluarga atau kelompok akan dilindungi oleh anggota keluarga atau kelompoknya. Namun sebagai gantinya, ia harus bersikap loyal terhadap keluarga atau kelompok tersebut (Hofstede, 2011). Tidak jarang seorang anak dari orangtua akan terus bersama orangtuanya sebagai bentuk perlindungan orangtua kepada anak dan sikap loyal anak kepada orangtua. Maka meskipun mahasiswa secara mayoritas memiliki usia perkembangan dewasa awal, namun orangtua masih bertanggung jawab dalam membimbing mahasiswa melalui pengasuhan.

Peneliti berargumen bahwa ketika mahasiswa mendapatkan kesempatan untuk mengenal dan menggunakan kekuatan karakternya melalui dukungan berupa pengasuhan orangtua, maka mahasiswa bisa lebih mengeksplorasi apa yang menjadi kekuatannya. Salah satu cara mengeksplorasi kekuatan pada mahasiswa adalah dengan melakukan tugas akademiknya di perkuliahan. Mungkin di awal, mahasiswa belum menemukan apa yang menjadi manfaat dari berbagai tuntutan perkuliahan yang diberikan kampus seperti proses belajar, pengerjaan tugas, dsb. Namun ketika ia mendapatkan hasil yang positif (nilai yang baik, pemahaman yang lebih baik, pujian dan lingkungan), ia bisa lebih terdorong untuk semakin melibatkan diri dengan perkuliahannya. Dukungan, pendampingan, umpan balik, kritik positif, pemberian fasilitas dari orangtua juga akan membiasakan mahasiswa untuk terus melibatkan diri dengan perkuliahan sehingga keterlibatan diri yang dimiliki mahasiswa semakin meningkat.

Salah satu komponen di dalam keterlibatan diri menurut Skinner, Kindremann, \& Furrer (2009) adalah komponen keterlibatan perilaku dan keterlibatan emosi. Keterlibatan perilaku dapat ditunjukkan melalui aitem nomor 1: "Saya berusaha keras utuk belajar dengan baik saat berada di kelas." Pada dasarnya perilaku berusaha keras untuk belajar merupakan salah satu bentuk kekuatan karakter. Demikianpun dengan keterlibatan emosi yang dapat ditunjukkan melalui aitem nomor 7: "Saya merasa tertarik untuk mengerjakan tugas saat berada di kelas." Kemampuan untuk merasa tertarik dalam belajar dan mengerjakan tugas juga merupakan bentuk kekuatan karakter. 
Philanthropy Journal of Psychology

Volume 4 Nomor 2 (2020), 143-157

ISSN 2580-6076 (Print), ISSN 2580-8532 (Online)

Mahasiswa yang sudah terbiasa untuk berusaha keras dalam belajar dan tertarik dalam mengerjakan tugas berarti juga sudah terbiasa untuk menggunakan kekuatan karakternya. Di dalam pengasuhan berbasis kekuatan karakter, penggunaan kekuatan karakter menjadi hal yang paling penting. Seseorang yang hanya mengetahui kekuatan karakter namun tidak pernah mendapatkan kesempatan untuk menggunakannya, kemungkinan kurang dapat mengembangkan diri dengan optimal (Jach, Sun, Loton, Chin, \& Waters, 2018; L. E. Waters, 2015; L. E. Waters et al., 2019; L. Waters \& Sun, 2016).

Hasil penelitian ini sejalan pula dengan penelitian yang dilakukan oleh Waters, dkk yang menunjukkan hasil bahwa pengasuhan berbasis kekuatan karakter memiliki korelasi yang cukup dengan keterlibatan diri di sekolah (L. E. Waters, Loton, \& Jach, 2019). Saat orangtua melakukan pengasuhan berbasis kekuatan karakter kepada mahasiswa, mereka akan membiasakan mahasiswa untuk mengenal kekuatan karakter yang dimilikinya dan kemudian menggunakannya dalam kehidupan sehari-hari, termasuk saat di perkuliahan. Ketika seseorang sudah dapat mengidentifikasikan apa yang menjadi kekuatan karakternya dan didukung untuk menggunakan kekuatan karakter tersebut secara teratur, ia akan menunjukkan peningkatan keterlibatan diri untuk belajar (Peterson \& Seligman, 2004, Madden, Green, \& Grant, 2011; Seligman, Ernst, Gillham, Reivich, \& Linkins, 2009).

Bronfenbenner (1977, dalam Papalia 2014) menyatakan bahwa orangtua merupakan lingkungan terdekat bagi individu. Begitupun pada mahasiswa, orangtua menjadi sumber terdekat baginya yang bisa membantu dalam perkembangan diri sesuai tahap perkembangannya. Saat mahasiswa diberikan kesempatan oleh orangtua untuk menggunakan kekuatan karakter, mahasiswa juga dapat berlatih mengembangkan keterampilan hidup. Keterampilan hidup tersebut bisa dimanfaatkan untuk melakukan adaptasi dengan lingkungan, melakukan tanggung jawab di lingkungan, dan sebagainya.

Pada akhirnya pemanfaatan keterampilan hidup pada mahasiswa yang diperoleh melalui kesempatan untuk menggunakan kekuatan karakter, akan memampukan mahasiswa menjalankan tugas dan fungsinya di lingkungan. Sejalan dengan pendapat Papalia (2014) yang menyatakan bahwa sebagai orang dewasa, salah satu tugas yang diemban oleh mahasiswa adalah mampu menjalankan fungsinya di lingkungan (Papalia, 2014). Demikian juga pendapat ahli psikologi positif yang menyatakan bahwa pada hakikatnya, manusia yang baik adalah manusia yang bisa menjalankan fungsinya dengan baik di lingkungan (Seligman, 2002). 
Philanthropy Journal of Psychology

Volume 4 Nomor 2 (2020), 143-157

ISSN 2580-6076 (Print), ISSN 2580-8532 (Online)

Adapun untuk dapat menjalankan fungsi sebagai mahasiswa, mahasiswa perlu menunjukkan antusiasme, minat, dan ketekunan di bidang pendidikannya. Di sinilah peran orangtua diperlukan untuk membantu mahasiswa. Orangtua dapat melibatkan dirinya untuk membimbing mahasiswa menemukan apa yang diminati dan menjadi kemampuannya di bidang pendidikan. Tantangan dapat diberikan dengan mengajak mahasiswa membuat target ingin meraih tujuan apa di bidang pendidikan. Umpan balik bisa diberikan tatkala mahasiswa mengalami hambatan dalam meraih tujuannya. Perilaku orangtua tersebut merupakan bentuk pengasuhan berbasis kekuatan karakter.

Ketika mahasiswa diberikan bimbingan dan tantangan di bidang pendidikan oleh orangtuanya, mahasiswa tersebut akan terdorong untuk mengenal dan menggunakan kekuatan karakter yang dimiliki. Kekuatan karakter pada mahasiswa dapat dilihat dari semakin terampil, semakin baik perasaan dan semakin sering mahasiswa untuk menunjukkan keterampilan, kemampuan, minat, karakter, sifat atau bakat yang dimilikinya (Waters, 2017). Misalnya, mahasiswa diberikan tantangan oleh orangtua untuk membuat target di bidang pendidikan seperti lulus tepat waktu. Mahasiswa tersebut akan mengusahakan untuk menggunakan kemampuannya dalam memahami pelajaran, bersikap tekun untuk menyelesaikan tugas, dan tidak mudah menyerah saat mengalami kesulitan. Mahasiswa pun dapat lebih termotivasi untuk mengikuti kegiatan perkuliahan. Motivasi ini nanti akan dimanifestasikan ke dalam perilaku, emosi dan kognitif mahasiswa untuk terlibat dalam kegiatan perkuliahan, terutama kegiatan belajar mengajar di kelas. Hal inilah yang disebut sebagai keterlibatan diri (Christenson, S. L., Wylie, C., \& Reschly, A. L., 2012).

Keterlibatan diri berbeda dengan motivasi yang lebih mengarah kepada alasan yang melatarbelakangi perilaku. Keterlibatan diri merupakan kombinasi perilaku, emosi dan kognitif sebagai manifestasi dari motivasi (Christenson, Wylie, \& Reschly, 2012). Pada mahasiswa, keterlibatan diri yang ditekankan dalam penelitian ini adalah keterlibatan diri terhadap kegiatan perkuliahan, terutama di dalam kelas. Keterlibatan diri dapat terlihat dari partisipasi mahasiswa dalam kegiatan belajar mengajar di kelas. Kualitas keterlibatan diri mahasiswa berkisar dari interaksi terhadap tugas akademik secara bersemangat, antusias fokus dan penghayatan emosi positif, sampai dengan menarik diri secara apatis (Skinner, E. A., Kindermann, T. A., \& Furrer, C. J., 2009).

Melalui penelitian ini juga diperoleh hasil uji deskriptif bahwa mean empirik $(77,46)>$ mean hipotetik $(67,5)$ keterlibatan diri yang berarti bahwa keterlibatan diri pada mahasiswa mengarah pada tinggi. Hal tersebut diperkuat dengan hasil perhitungan kategorisasi yang menunjukkan 
Philanthropy Journal of Psychology

Volume 4 Nomor 2 (2020), 143-157

ISSN 2580-6076 (Print), ISSN 2580-8532 (Online)

bahwa 39,9\% mahasiswa memiliki keterlibatan diri yang tinggi dan 18,4\% mahasiswa memiliki katerlibatan diri yang sangat tinggi. Artinya mahasiswa menghayati dirinya sudah menunjukkan perilaku, emosi dan kognitif yang betul-betul terlibat dengan aktivitas belajar-mengajar di perkuliahan. Misalnya, mahasiswa bersedia untuk melakukan diskusi dengan aktif, memusatkan perhatian, dan merasa senang ketika melakukan aktivitas belajar-mengajar di perkuliahan. Hal ini menjadi tanda yang baik, karena keterlibatan diri dapat menjadi prediktor yang baik terhadap keberhasilan akademik nantinya (Fredricks, Blumenfeld, Friedel, \& Paris, 2003).

Hasil uji deskriptif lain menunjukkan bahwa mean empirik pengasuhan berbasis kekuatan karakter $(51,77)>$ mean hipotetik pengasuhan berbasis kekuatan karakter (42) yang berarti bahwa pengasuhan berbasis kekuatan karakter yang dilakukan orangtua kepada mahasiswa mengarah pada tinggi. Hal tersebut diperkuat dengan hasil perhitungan kategorisasi yang menunjukkan bahwa 73\% mahasiswa menghayati bahwa pengasuhan berbasis kekuatan karakter yang dilakukan orangtua berada dalam kategori tinggi (high use). Artinya, mahasiswa menyetujui bahwa orangtuanya telah melakukan pengasuhan berbasis kekuatan karakter kepada mereka. Pengasuhan berbasis kekuatan karakter sendiri dapat digolongkan ke dalam 4 kategori utama, berdasarkan dari norma mutlak yang sudah ditetapkan Lea Waters, yaitu rendah (low), sedang (medium), tinggi (high use), dan sangat tinggi (super) (Waters, 2017). Semakin tinggi kategori pengasuhan berbasis kekuatan karakter, maka semakin tinggi pengetahuan orangtua terhadap kekuatan karakter yang dimiliki mahasiswa dan semakin tinggi pula kecenderungan orangtua untuk membantu mahasiswa dalam menggunakan kekuatan karakternya.

\section{Simpulan}

Berdasarkan hasil penelitian yang dilakukan terhadap mahasiswa mengenai hubungan pengasuhan berbasis kekuatan karakter dan keterlibatan diri dapat ditarik kesimpulan bahwa terdapat hubungan positif yang signifikan antara pengasuhan berbasis kekuatan karakter dan keterlibatan diri pada mahasiswa dengan koefisien korelasi $r=0,455(p=0,000=<0,01)$. Semakin tinggi pengasuhan berbasis kekuatan karakter maka akan semakin tinggi pula keterlibatan pada mahasiswa dalam kegiatan perkuliahannya. Artinya akan lebih baik jika orangtua dapat melakukan pengasuhan berbasis kekuatan karakter dengan kategori penggunaan yang tinggi (high use) dan sangat tinggi (super) agar keterlibatan diri mahasiswa terhadap perkuliahan pun tinggi.

Adapun saran yang diperoleh dari hasil penelitian ini adalah:

1. Orangtua perlu melakukan pengasuhan berbasis kekuatan karakter untuk membantu mahasiswa lebih terbiasa dalam mengenal dan menggunakan kekuatan karakter yang dimiliki, 
Philanthropy Journal of Psychology

Volume 4 Nomor 2 (2020), 143-157

ISSN 2580-6076 (Print), ISSN 2580-8532 (Online)

sehingga mahasiswa juga bisa lebih terlibat dalam kegiatan perkuliahan. Bagi orangtua yang belum mencapai pengasuhan berbasis kekuatan karakter dalam golongan penggunaan yang tinggi (high use) dan sangat tinggi (super), diharapkan terus membiasakan diri untuk lebih mengenal kekuatan karakter mahasiswa dan mendorong mahasiswa untuk menggunakan kekuatan karakternya secara terus menerus sehingga mahasiswa dapat meningkatkan keterlibatan diri terhadap perkuliahan.

2. Beradasarkan hasil penelitian, koefisien korelasi yang diperoleh adalah $r=0,455(p=0,000=<$ 0,01). Artinya, walaupun korelasinya positif dan signifikan, namun korelasi ini baru sebatas cukup. Perlu ada penelitian lebih lanjut untuk mengetahui peranan variabel lain yang dapat memediasi hubungan antara pengasuhan berbasis kekuatan karakter dan keterlibatan diri sehingga diketahui dinamika hubungan kedua variabel ini secara lebih mendalam.

3. Untuk penelitian lanjutan, peneliti dapat melakukan penelitian tentang penghayatan mahasiswa terhadap pengetahuan kekuatan karakter dan penggunaaan karakter untuk memastikan apakah pengasuhan berbasis kekuatan karakter memang berdampak terhadap mahasiswa.

4. Penelitian selanjutnya juga dapat mempertimbangan untuk meneliti faktor internal seperti usia dan kematangan kognitif maupun faktor eksternal seperti dukungan teman, budaya, dan iklim belajar di kampus. Sehingga didapatkan uji hubungan faktor internal dan eksternal dengan keterlibatan diri.

\section{Kepustakaan}

Azwar. (2012). Metode Penelitian. Yogyakarta: Pustaka Pelajar.

Christenson, S. L., Wylie, C., \& Reschly, A. L. (2012). Handbook of Research on Student Engagement. Handbook of Research on Student Engagement, (January 2012), 1-840. https://doi.org/10.1007/978-1-4614-2018-7

Fredricks, J. A., Blumenfeld, P., Friedel, J., \& Paris, A. (2003). Linking engagement to achievement. Child Trends, 1-49.

Heffner, Ashley L., Susan P. Antaramian. (2015). The Role of Life Satisfaction in Predicting Student Engagament and Achievement. J Happiness Stud (2016) 17 : 1681- 1701.

Jach, Hayley K., Jessie Sun., Daniel Loton., Tan-Chyuan Chin; Lea E. Waters. (2018). Strengths and Subjective Wellbeing in Adolescence: Strength-Based Parenting and the Moderating Effect of Mindset. J Happiness Stud (2018) 19: 567 - 586.

Kyriazos, T. A., \& Stalikas, A. (2018). Positive Parenting or Positive Psychology Parenting? Towards a Conceptual Framework of Positive Psychology Parenting. Psychology, 09(07), 1761-1788. https://doi.org/10.4236/psych.2018.97104 
Philanthropy Journal of Psychology

Volume 4 Nomor 2 (2020), 143-157

ISSN 2580-6076 (Print), ISSN 2580-8532 (Online)

Madden, W., Green, S., \& Grant, A. M. (2011). Enhancing engagement and hope. International Coaching Psychology Review, 6(1), 71-130.

Papalia, Diane E,. (2014). Experience Human Development (13th International Edition). New York: McGraw Hill Higher Education

Peterson, C., \& Seligman, M. P. (2004). Character strengths and virtues: A handbook and classification. New York: Oxford University Press

Seligman, M. E. (2002). Authentic Happiness: Using the New Positive Psychology to Realize Your Potential for Lasting Fulfillment. New York, NY: Free Press.

Seligman, M. E. P., Ernst, R. M., Gillham, J., Reivich, K., \& Linkins, M. (2009). Positive education: Positive psychology and classroom interventions. Oxford Review of Education, 35(3), 293-311. https://doi.org/10.1080/03054980902934563

Skinner, E. A., Kindermann, T. A., \& Furrer, C. J. (2009). A motivational perspective on engagement and disaffection: Conceptualization and assessment of children's behavioral and emotional participation in academic activities in the classroom. Educational and Psychological Measurement, 69(3), 493-525. https://doi.org/10.1177/0013164408323233

Skinner, E., Furrer, C., Marchand, G., \& Kindermann, T. (2008). Engagement and Disaffection in the Classroom: Part of a Larger Motivational Dynamic? Journal of Educational Psychology, 100(4), 765-781. https://doi.org/10.1037/a0012840

Steinberg, L., Lamborn, S. D., Dornbusch, S. M., \& Darling, N. (1992). Impact of Parenting Practices on Adolescent Achievement: Authoritative Parenting, School Involvement, and Encouragement to Succeed. Child Development, 63(5), 1266-1281. https://doi.org/10.1111/j.14678624.1992.tb01694.x

Tian, Lili., Jie Zhao., E. Scott Huebner. 2015. School-related Social Support and Subjective Well-Being in School Among Adolescents: The Role of Self-system Factors. Journal of Adolescence 45 (2015) $138-148$.

Waters, L. E. (2015). Strength-based parenting and life satisfaction in teenagers. Advances in Social Sciences Research Journal, 2(11), 158-173. https://doi.org/10.14738/assrj.211.1551

Waters, L., \& Sun, J. (2016). Can a Brief Strength-Based Parenting Intervention Boost Self-Efficacy and Positive Emotions in Parents? International Journal of Applied Positive Psychology, 1(1-3), 41-56. https://doi.org/10.1007/s41042-017-0007-x

Waters, Lea. 2017. The Strength Switch: How The New Science Of Strength-Based Parenting Can Help You And Your Child Flourish. Avery: New York.

Waters, L. E., Loton, D., \& Jach, H. K. (2019). Does Strength-Based Parenting Predict Academic Achievement? The Mediating Effects of Perseverance and Engagement. Journal of Happiness Studies, $\quad 20(4), \quad$ 1121-1140. https://doi.org/10.1007/s10902-018-9983-1 